\title{
The Effect of Personal Economic Values on Economic Policy Preferences*
}

Amanda Friesen, Indiana University-Purdue University Indianapolis

Department of Political Science, CA504J, 425 University Blvd., Indianapolis, IN 46202.

amfriese@iupui.edu

Matthew V. Hibbing, University of California, Merced

Department of Political Science, 5200 North Lake Rd, Merced, CA 95343.

mhibbing@ucmerced.edu

*Direct all correspondence to: Amanda Friesen, IUPUI, who also will share all data for coding and replication purposes. The authors wish to thank John Hibbing and Kevin Smith for their helpful feedback as well as sharing survey space on their 2010 study funded by the National Science Foundation (BCS-0826828).

Abstract: Objectives: Citizens often express that the government should be run like a business or household in the way that money is saved and spent, though individuals vary in their personal financial preferences and attitudes toward money. To explore the relationship between the personal and political, we draw upon research in psychology, economics and consumer science on personal economic values, such as materialism and the importance of saving money. Methods: Using a survey of 340 adults, we test connections between political ideology, the Big 5 personality traits and money conservation and material values. Results: Our data suggests that values regarding personal money conservation are unrelated to economic policy attitudes like welfare spending and wealth redistribution, but the value individuals place on material items is predictive of these political preferences. Conclusion: By showing the political significance of personal (and non-political) materialism values, we contribute to a rapidly growing literature, which shows that political attitudes and behaviors are best understood in the context of the larger social world.

This is the author's manuscript of the article published in final edited form as:

Friesen, A., \& Hibbing, M. V. (2016). The Effect of Personal Economic Values on Economic Policy Preferences. Social Science Quarterly. http://doi.org/10.1111/ssqu.12236 


\section{Introduction}

The U.S. government spent approximately 3.7 trillion dollars in 2011. The national debt stands at over 15 trillion dollars. These figures are the source of great consternation for many Americans who perceive them as signs of rampant fiscal irresponsibility in Washington. Many of these citizens express incredulity that the federal government can engage in fiscal practices that would never be acceptable for the average American attempting to live within their means. In popular press reports it is not at all uncommon to hear quotes like: "If I ran my small business the way the government is run, I'd go out of business!" or "My family makes a budget and sticks to it, why can't the government do the same?"

Setting aside the validity of the comparison between household finances and a $\$ 15$ trillion national economy, it is telling to note the way ordinary Americans seem to translate their personal values regarding responsibility and moderation to the political realm. We build upon this observation by probing the connection between personal values relating to money and broader economic political attitudes. In doing so, we draw upon research in psychology, economics and consumer science which has sought to theoretically conceptualize and measure personal economic values such as materialism and the importance of saving money. We theorize that these personal values play an important role in structuring political attitudes across a range of economic domains.

The motivating logic of our study is simple. Economic issues are often abstract and complex, often dubbed "hard issues" (Carmines and Stimson, 1980). Consider an issue such as government intervention during a recession where economists disagree sharply over the value of deficit spending. If economic experts cannot agree on the proper course of action, it seems unlikely that an ordinary person will be able to form an attitude without the help of some kind of shortcut. 
Political scientists have acknowledged this and devoted attention to the importance of partisanship and ideology, concepts that undoubtedly play a crucial role in shaping economic attitudes. However, comparatively little attention has been given to personal circumstances and orientations that could provide people with guidance. It seems reasonable to expect that citizens will draw upon their own personal economic values and experiences when making decisions about the economy at large. Following this intuition, we draw upon research on personal economic values to guide our theorizing and test our hypotheses using data from a representative but geographically constrained survey.

\section{Fiscal Policy Preferences}

When considering the sources of economic issue attitudes, scholars have traditionally focused on partisan identification, which posits that identification with a party is a longstanding psychological attachment, formed early in life in response to childhood socialization and remains relatively stable throughout life (Campbell et al., 1960). Research following in this tradition (e.g. Miller and Shanks, 1996; Green, Palmquist, and Shickler, 2002) has conceived of partisanship as an "unmoved mover" that influences political attitudes, but is not influenced in turn. This work has been challenged by a group of scholars who flip the causal story by viewing party identification as a "running tally," which aggregates political attitudes and economic judgments of party performance (see Downs, 1957; Fiorina, 1981; Achen, 1992). Despite continued debate (e.g. Gerber and Green, 1998; MacKuen, Erikson, and Stimson, 1989), the prevailing view continues to place partisanship as an important, causal factor in shaping political orientations (Bartels, 2002), albeit with qualifications based on citizens' awareness of the parties' positions on salient issues (Carsey and Layman, 2006).

A second, related literature has conceived of mass political attitudes as resulting from the interplay between ordinary citizens and political elites. This work has primarily viewed the mass public as reactive to the decisions of elites regarding which issues to politicize (Carmines and 
Stimson, 1989) and how to frame those issues (Zaller, 1992). The major parties differ in how they frame government spending, and citizens respond accordingly (Jacoby, 2000). These top-down models of attitude formation merge with the partisan identification literature discussed above because citizens look to elites of their own party to help them make judgments about current political topics.

A third strand of literature has investigated the role of "core values" in shaping political orientations. This research promotes the notion that people have stable and consistent views about the general desirability of certain human outcomes (e.g. Rokeach, 1973; Schwartz, 1992). Political scientists have examined the influence of a variety of principles, including free enterprise, economic individualism, equality of opportunity (Feldman, 1988), humanitarianism (Feldman and Steenbergen, 2001), equality of outcome, and freedom of expression (Grant and Rudolph, 2003), just to name a few (see also, e.g., Marcus et al., 1995; McClosky and Zaller, 1984).

Research on values has provided a number of insights into the important role played by longstanding dispositions in influencing political orientations. However, one common criticism of this literature points out that concepts like "freedom," "liberty," and "equality" are lofty and abstract (Maio and Olson, 1998). Given what we know about low levels of citizen knowledge (Delli-Carpini and Keeter, 1996) and limited ideological constraint (Converse, 1964; Zaller, 1992), Americans may not be able to connect abstract values to concrete problems. It also suggests that a fruitful avenue of study would be to examine more tangible, localized values that the citizens can easily link to political issues without much cognitive effort. Personal economic values that citizens apply to their household budgets and spending habits could provide guidance in the formation of political attitudes more readily than abstract principles regarding freedom and equality.

The research that has most directly examined the influence of personal economic considerations on larger political orientations is work on economic voting and symbolic politics. The 
economic voting literature has sought to understand the degree to which citizen vote choice results from consideration of the national economy ("sociotropic voting") versus a consideration of only personal financial experiences ("pocketbook voting"). Work in the symbolic politics tradition (e.g. Sears et al. 1980; Sears and Funk 1991; Sears 1993) similarly contrasts self-interest with symbolic attitudes (e.g. ideology, party ID, racial prejudice). The prevailing conclusion has been that sociotropic and symbolic considerations trump pocketbook and self-interest considerations when it comes to vote choice (see e.g. Kiewiet, 1983; Kinder and Kiewiet, 1979; MacKuen, Erikson, and Stimson, 1992) and social and political attitudes (Sears et al. 1980; Sears and Funk 1991). This relative priority of national economic considerations over personal ones should not obscure the possibility that personal considerations have a role to play, for at least three reasons. First, there is some evidence that pocketbook considerations do matter in economic voting (e.g. Lewis-Beck, 1985), and just because these effects are small in comparison to sociotropic concerns does not mean

they are not important to consider. Second, economic considerations can influence political attitudes even if the influence on vote choice is subsumed by larger national-level considerations. For example, a recent study revealed that shared partisanship with the White House influences perceptions of individuals' personal finances (Weinschenk, 2012). Finally, and most importantly, this work has centered entirely on objective or perceived personal conditions. In the present study we move away from a focus on self-interest relevant conditions, and instead turn our attention to personal economic values and the potential for these values to influence judgments regarding national-level economic policy.

\section{Personal Economic Values}

Over the last half decade, a substantial body of research has built up demonstrating that political orientations are influenced by decidedly "non-political" factors such as personality traits, cognitive ability, and physiological sensitivity to stimuli (see e.g. Amodio et al., 2007; Denny and 
Doyle, 2008; Mondak, 2010; Oxley et al., 2008; Smith et al., 2011). From this work, we draw the insight that political attitudes are likely to be shaped by general, broad orientations and values. Here we focus on a set of values that capture how individuals think and feel about their own money. These "personal economic values" could provide ordinary citizens with useful guidance as they attempt to navigate the complicated economic issues in play at the level of national politics. To measure these values, we rely on research from psychology, economics, and consumer behavior, which has developed robust measures of personal economic values that we can apply to the study of politics.

We are particularly interested in two distinct values: money conservation (also sometime called "saving" or "budgeting") and materialism. Money conservation refers to an individual's desire (and ability) to make and stick to a budget in their personal finances. It is typically measured through items like, "I use my money very carefully" or "I prefer to save money because I'm never sure when things will collapse and I will need the cash” (Tang, 1992; Troisi, Christopher, and Marek, 2006). Budgeting is positively associated with age and income as well as life satisfaction (Tang, 1992). Though "budgeting" is a positive frame of this aspect of personality, other scholars have suggested that those who are extremely tight with money report lower levels of well-being (Troisi Christopher, and Marek, 2006; Tatzel, 2002). We expect that individuals who are prone to money conservation (“savers") will apply those same values to the political domain by adopting conservative issue positions on questions of taxation and government spending.

Materialism refers to how possessing physical items may confer meaning, a sense of success or even happiness in an individual's life. Individuals with high scores on materialism believe that there is a close link between their possession of material goods and their own happiness and would agree to statements such as "Buying things give me a lot of pleasure," and "My life would be better if I owned certain things I don't have." Within the materialism battery of questions, three factors 
generally emerge that reflect the nuanced meaning that possessions convey for different individuals: Success, Centrality and Happiness. Some individuals value material items because they are indicative of one's success in life; others see the procurement of possessions as central to one's existence; and still others find happiness in buying and owning things (Richins and Dawson, 1992; Tatzel, 2002).

Materialism has been linked to attitudes toward debt, impulse buying and mental health (Troisi, Christopher, and Marek, 2006; Tatzel, 2002; Richins, 2004; Giddens, Schermer and Vernon, 2009). Those high in materialism and low in money conservation are more comfortable with debt and impulse-buying as compared to their less materialistic, penny-pinching counterparts. There also appears to be an interaction with income where essentially those who value items and have the cash to purchase them report higher levels of "well-being" than those who are cash-strapped but desire the same amount of possessions (Troisi, Christopher, and Marek, 2006, 422). These measures are predictive of preferences for debt and some types of personal spending.

Most of the work involving personal economic values has examined their role in predicting other items, such as risk-taking or impulsivity (Troisi, Christopher and Marek, 2006) without necessarily testing what might explain variance in the measures themselves. We are interested in understanding how personal economic values relate to both demographic items that explain many phenomena in the social sciences as well as the Big 5 personality traits that are often used as the baseline traits from which other attitudes emerge. We hypothesize that conscientiousness is a major influence on personal economic values such that individuals high in conscientiousness will be more inclined to be "savers" and to view material goods as important for success. These expectations stem from the very definition of conscientiousness, which incorporates subsidiary characteristics including "responsibility" and "self-control” (Roberts et al., 2005).

H1: Higher scores on conscientiousness will be positively associated with money conservation and negatively associated with materialism. 
Our second expectation regarding the personality underpinnings of personal economic values relates to the trait "emotional stability." Individuals who are high in emotional stability tend to possess healthy impulse control, which suggests an ability to save their money. We also expect that emotional stability will be negatively related to our various measures of materialism. An emotionally stable person seems unlikely to require the external validation suggested by the pursuit of material goods. Existing work on the political consequences of emotional stability shows similar effects to those obtained for conscientiousness in that both are predictive of more conservative issue positions (Mondak, 2010).

H2: Higher scores on emotional stability will be positively associated with money conservation and negatively associated with materialism.

Because we expect some of the Big 5 traits to be related to personal economic values and the former are also linked to political attitudes, we expect that money attitudes could also be related to attitudes on government spending. In one of the few analyses that examined personal economic values and political beliefs, Furnham (1996) found that individuals who valued physical possessions were more likely to label themselves as right-wing, regardless of their tendency to save or spend freely. This link between personal economic values and political views could be a mediating factor between personality traits and political attitudes (Mondak et al., 2010). It is well established that the Big 5 personality trait "conscientiousness" is associated with more conservative economic issue positions and ideological self-placement (Mondak, 2010). Thus, we expect that contrary to the economic voting literature that suggests individuals eschew personal economic conditions, we think that general attitudes about money will translate from the personal to the political.

For similar reasons, we also expect those who place higher values on material possessions to exhibit conservative attitudes toward government spending and wealth redistribution. If materialistic individuals believe material items convey success, are central to life and bring happiness, then they 
will likely oppose policies that will damage their social status by "unfairly" taking their personal wealth and distributing it to others.

H3: Money conservation and materialism will be associated with conservative attitudes on government spending.

\section{Data and Measures}

In order to examine the relationships between personality, personal economic values, and fiscal policy preferences, we included relevant items on a survey conducted in the summer of 2010. A professional surveying agency sent letters to a random sample of adults in a Midwestern city, resulting in 340 individuals participating in a computer-based survey and experiment at a nearby college campus in exchange for $\$ 50$. Though not a representative, national sample, the average participant was 45 years old, has had some college education and earns $\$ 60,000$ annually. The sample also was 55\% women and 95\% white. Because income will influence economic issue attitudes, it is important to recognize that this sample's mean was higher than the national average, though there was a normal distribution.

The Big Five. We administered the Ten-item Personality Inventory (TIPI) to our participants and created two-item additive indices for each trait. The TIPI has been found to provide valid measures of the Big Five when compared to more extensive trait batteries (Gosling, Rentfrow, and Swann 2003) and has been widely used in political behavior research (Gerber et al. 2011). Descriptive information on our Big Five measures can be found in the online appendix.

Materialism and Conservation. Scales that measure orientations toward materialism may contain up to 18 items. A sub-set of five was used in the current study (Richins 2004), and participants indicated whether they agreed or disagreed on a five-point scale. Of the five materialism items in this study, two were taken from the Centrality subset (Cronbach's alpha $=.47$ ), two from Success $($ Cronbach's alpha $=.67)$, and one from Happiness, the three subscales that are typically used in the literature (Richins, 2004; Giddens, Schermer, and Vernon, 2009). The items were coded such that 
higher scores indicate participants agree that material possessions are central to their lives, indicative of their success or the key to happiness. ${ }^{1}$ In addition, three money conservation items (Cronbach's alpha $=.71)$ were selected from an 11-item scale, and participants indicated agreement on a fivepoint scale with the statements (Troisi, Christopher and Marek, 2006). Four additive indices were created from the associated materialism and conservation items and averages created as the subscales did not contain the same number of items. The three materialism indices are significantly and positively correlated with one another, but only Material Centrality has a significant relationship with Money Conservation $(\mathrm{r}=-.15, \mathrm{p}=.01)$, such that the more that possessions are central to one's life, the less likely one is to conserve money.

\section{Results}

We begin with an examination of the personality basis of personal economic values. Table 1 displays the results of regression models for each of the four personal economic values: material success, material centrality, material happiness, and money conservation. The key independent variables are the Big Five personality traits, with controls included for age, gender, income, and education. As predicted, conscientiousness is associated with higher levels of Money Conservation $(\mathrm{B}=.11, \mathrm{p}<.001)$. The results for Materialism are mixed. Conscientious individuals were less likely to view possessions as central to their lives $(\mathrm{B}=-.05, \mathrm{p}<.05)$ as we predicted. However, they also were more likely to view material items as indicative of success $(B=.01, p<.05)$, suggesting that conscientiousness differentially effects the meaning one puts on material items, not necessarily the general desire for those items. The other main finding in our analysis of the Big 5 is that emotional stability is negatively related to all three measures of materialism. The more emotionally stable one saw oneself, the less likely they were to be materialistic, which supports previous literature on the

\footnotetext{
${ }^{1}$ More information about the survey instrument, coding and scale reliability can be found in the online appendix.
} 
effects of materialism on well being in that the need for material items to convey meaning demonstrates emotional instability (Troisi, Christopher, and Marek, 2006).

[Table 1 about here]

Notably, age was significantly associated with each personal economic value, such that younger participants reported higher scores on materialism and lower scores on money conservation, supporting findings in the personal economic values literature (Troisi, Christopher and Marek, 2006). Income was positively associated with Material Centrality and negatively associated with Material Happiness as increases in income indicate beliefs that possessions are central to one's life but that they are not indicative of happiness. Being female had opposite effects on the dependent variables as men were more likely to indicate material items are a measure of success $(B=-.24, \mathrm{p}<.05)$ and happiness $(\mathrm{B}=-.32, \mathrm{p}<.01)$, and women were more likely to indicate material items were central to their lives $(\mathrm{B}=.33, \mathrm{p}<.001)$. These findings make a great deal of sense when we consider the sizeable body of research, which indicates that material possessions serve different purposes for men and women. Men value possessions for instrumental reasons, focusing on possessions related to leisure and finances, while women favor possessions that have sentimental or symbolic value (see e.g. Dittmar, 1989; Dittmar, Beattie, and Friese, 1995; Wallendorf and Arnould, 1988).

Economic values seem to be related to some aspects of the Big 5 as well as key demographic variables. What does this mean for political attitudes? For example, we know that Conscientiousness is associated with political conservatism; can we assume money conservation is as well? Table 2 displays bivariate relationships between the money attitude factors and ideology and partisanship. Participants were asked to place themselves on a five-point ideological scales, from 1 or "liberal" to 5 or "conservative" $(\mathrm{M}=3.16, \mathrm{SD}=1.20)$, as well as a 7 -point party identification scale from "strong Democrat" to "strong Republican" ( $\mathrm{M}=4.02, \mathrm{SD}=1.91)$. Ideology and party identification were 
strongly correlated in these samples $(\mathrm{r}=.68, \mathrm{p}<.001)$. As expected, ideology was positively associated with Money Conservation, with conservatives more likely to watch their money carefully $(\mathrm{r}=.12, \mathrm{p}<.05)$. The only relationship between ideology and the materialism items was a weak, negative correlation with Centrality $(\mathrm{r}=-.10, \mathrm{p}<.10)$.

[Table 2 about here]

Because self-reported ideology may capture both social and economic dimensions (Miller and Schofield, 2003; Asher, 1980; Conover and Feldman, 1981; Weisberg and Rusk, 1970), we wish to test the influence of personal money dispositions on specific fiscal attitudes. We expect that those careful with their money will be opposed to government spending, applying their personal values to fiscal policy. In keeping with the only extant literature on personal economic values and political orientations (Furnham, 1996), we also expect that those high in materialism will express conservative attitudes on fiscal policy. Because material possessions are important indicators of success and happiness to material individuals, they will be against the government reducing their ability to get these items through taxation and wealth redistribution.

Our fiscal policy measures were taken from the Wilson-Patterson Index, as participants were asked whether they agreed or disagreed, on a five-point scale, with a series of items: "increase welfare spending" $(M=2.45, \mathrm{SD}=1.02)$, "increase military spending” $(\mathrm{M}=3.09, \mathrm{SD}=1.07)$, and "lower taxes" $(\mathrm{M}=3.84, \mathrm{SD}=.98)$, with scores coded such that higher values indicate more conservative positions. Another item from a "thinking about politics" battery identified agreement with wealth distribution $(\mathrm{M}=2.99, \mathrm{SD}=1.32)$. Table 3 displays results of the policy preferences regressed on personal economic values and demographic variables. Surprisingly, Money Conservation was unrelated to attitudes toward government spending and wealth redistribution, contrary to our hypothesis. It does support the socio-tropic voting literature that suggests individuals 
do not necessarily associate their personal pocketbooks with the national economy, or in this case, how the government should spend its money (Kiewiet, 1983; Kinder and Kiewiet, 1979). ${ }^{2}$

[Table 3 about here]

Our materialism hypothesis was partially supported in that individuals who score higher on Centrality held more conservative views on wealth distribution and lower taxes, indicating that those who see their possessions as central to their lives are opposed to the government taking away their wealth, possibly because it could limit their ability to acquire more things. Material Happiness showed a similar relationship with conservative views on lower taxes. On the other hand, Happiness $\mathrm{B}=-.26, \mathrm{p}<.001)$ and Success $(\mathrm{B}=-.16, \mathrm{p}<.05)$ were negatively associated with conservative views on distributing wealth more evenly, suggesting that perhaps those individuals who believe their life would be better if they owned more things and that things are indicative of success think that everyone should have the opportunity to purchase items to improve their lives. None of the personal economic values were related to preferences for military or welfare spending, which is perhaps expected considering these are very common items that split along ideological lines, and individuals may solely be relying upon elite cues. For example, military spending may have more to do with views on foreign policy and security than pure financial preferences, and welfare beliefs often are conflated with attitudes about race (Gilens, 2000).

It seems that the personal and political do not overlap in preferences for saving and spending but that values relating to material items are more predictive of political positions. Using specific economic issues reveals different relationships than the broader ideological measure as Money Conservation was significantly associated with self-reported ideology as conservatives were

\footnotetext{
2 Separate models were performed on these dependent variables with the inclusion of the Big 5 personality traits as covariates. The results for the personal economic attitudes did not change substantially but this information is included in the online appendix.
} 
more likely to indicate saving ${ }^{3}$, though this did not translate to their attitudes on government spending. Furthermore, the relationships between Material Success, Centrality and Happiness and conservatism flipped when moving from a general ideological measure to specific fiscal preferences. Because of the strong relationships between Money Conservation, Conscientiousness and selfreported ideology (conservatism), it seems possible that a propensity toward saving money is latently related to an orientation toward something like caution or prudence, but this does not necessarily mean that individuals are applying their personal money values to the political world of spending.

\section{Discussion}

Individuals differ in how they think and feel about money and material possessions. Some people value the security provided by a clean balance sheet and a healthy savings account, while others spend freely with little concern for future consequences. Some people like to spend their money on material possessions, and they see those possessions as central to their happiness and well-being, while others value the distinctive life experiences that money can provide more than the material goods it can buy. In this paper we have established that these differences in how individuals value money can, at least in part, be accounted for by a combination of individual personality traits and life circumstances. More importantly, we also have demonstrated that these personal economic values have political consequences, in one of the first examinations of personal economic values and fiscal policy preferences. Our findings provide insights for several lines of political inquiry.

First, by showing the political significance of personal (and decidedly non-political) materialism values, we contribute to a rapidly growing literature which shows that political attitudes and behaviors are best understood in the context of the larger social world (e.g. Amodio et al., 2007; Denny and Doyle, 2008; Mondak, 2010; Oxley et al., 2008; Smith et al., 2011). That is, political

\footnotetext{
3 Even when controlling for age, sex, income and education, there is a positive relationship between Money Conservation and self-reported ideology $(\mathrm{p}=.07)$ such that increases in saving are associated with conservatism.
} 
orientations develop alongside other beliefs and behaviors, such as the way an individual processes information, attends to his or her environment, interacts with others, and exhibits certain personality traits. Politics is not a central feature in the lives of most citizens, so it should not be surprising to find that when confronted with political choices, the average person will construct their attitude from what is available and salient. Zaller (1992) made this point in connection to available political information, but the logic seems equally applicable to non-political considerations. Our personality traits and our social values are also likely to be important factors in shaping the kinds of political views we espouse.

A second point to note about our findings is that they demonstrate that the relationship between personal material values and political views is more nuanced than one might expect. We found that individual propensity to save money was not related to any of the political attitudes under study here. This is somewhat surprising considering how easy it would be for people to make a direct connection between their own spending and saving and the practices of the federal government. Indeed, this kind of personalized rhetoric regarding federal budget deficits was a significant motivator in our pursuit of this research question. Our null findings on this point lend support to the literatures on economic voting and symbolic politics, which emphasizes sociotropic considerations ahead of personal circumstances (Kiewiet, 1983; Kinder and Kiewiet, 1979; MacKuen, Erikson, and Stimson, 1992; Sears et al. 1980; Sears and Funk 1991). However, before we totally dismiss the political significance of personal attitudes towards saving, it would be useful to examine a wider array of dependent variables than we had available in our data. Our items only indirectly tap attitudes towards government debt and balanced budgets, which are two concepts that seem particularly likely to be influenced by personal orientations toward debt. It also may be helpful to examine specific attitudes about budgeting or the types of possessions that are likely to convey success or generate happiness. Is it the case that those who desire a flashy car may differ in their 
policy preferences from a person who wears designer clothes or wants a nice house? Regardless, our findings suggest that orientations toward material items, which may seem completely removed from the political world, seem to inform preferences related to the amount of money the government tries to take away (support for lower taxes) and whether wealth should be more evenly distributed, even when controlling for self-reported ideology. Because the relationship with money conservation is absent on these items, it may not be the presence or accumulation of money that connects the personal and political. Instead the instrumental value of money, or what it can buy, may become this outward symbol of one's success or central to one's existence and translate into attitudes about all citizens having enough.

\section{References}

Achen, C. H. (1992). "Social Psychology, Demographic Variables, and Linear Regression: Breaking the Iron Triangle in voting Research." Political Bebavior, 14, 195-211.

Amodio, D. M., J. T. Jost, S. L. Master, and C. M. Lee. (2007). "Neurocognitive Correlates of Liberalism and Conservatism." Nature Neuroscience, 10, $1246-7$.

Bartels, L. M. (2002). "Beyond the Running Tally: Partisan Bias in Political Perceptions.” Political Behavior, 24, 117-50.

Campbell, A., P. E. Converse, W E. Miller, and D. E. Stokes. (1960). The American Voter. Chicago: The University of Chicago Press.

Carmines, E. G., and J. A. Stimson. (1980). "The Two Faces of Issue Voting." American Political Science Review, 74, 78-91.

Carmines, E. G., and J. A. Stimson. (1989). Issue Evolution: Race and the Transformation of American Politics. Princeton: Princeton University Press.

Carsey, T. M., and G. C. Layman. (2006). "Changing Sides or Changing Minds? Party Identification and Policy Preferences in the American Electorate." American Journal of Political Science, 50, 464-77.

Converse, P. E. (1964). “The Nature of Belief Systems in Mass Publics.” In Ideology and Discontent, ed. D. Apter. New York: Free Press, (pp. 206-61).

Delli-Carpini, M. X., and S. Keeter. (1996). What Americans Know about Politics and Why It Matters. New Haven: Yale University Press.

Denny, K., and O. Doyle. (2008). "Political Interest, Cognitive Ability and Personality: Determinants of Voter Turnout in Britain." British Journal of Political Science, 38, 291-310.

Dittmar, H. (1989). "Gender Identity-Related Meanings of Personal Possessions." British Journal of Social Psychology, 28, 159-171.

Dittmar, H., J., Beattie, and S. Friese. (1995). "Gender Identity and Material Symbols: Objects and Decision Considerations in Impulse Purchases." Journal of Economic Psychology, 16, 491-511.

Downs, A. (1957). An Economic Theory of Democracy. New York: Harper and Row. 
Feldman, S. (1988). "Structure and Consistency in Public Opinion: The Role of Core Beliefs and Values." American Journal of Political Science, 32, 416-40.

Feldman, S., and M. Steenbergen. (2001). "The Humanitarian Foundation of Public Support for Social Welfare." American Journal of Political Science, 45, 658-77.

Fiorina, M. P. (1981). Retrospective Voting in American National Elections. New Haven: Yale University Press.

Furnham, A. (1996). "Attitudinal Correlates and Demographic Predictors of Monetary Beliefs and Behaviors.” Journal of Organizational Behavior, 17 (4), 375-388.

Gerber, A., and D. P. Green. (1998). "Rational Learning and Partisan Attitudes." American Journal of Political Science, 42, 794-818.

Gerber, A. S., G. A. Huber, D. Doherty, and C. M. Dowling. (2011). “The Big Five Personality Traits in the Political Arena." Annual Review of Political Science, 14, 265-287.

Giddens, J. L., J. A. Schermer, and P. A. Vernon. (2009). "Material Values Are Largely in the Family: A Twin Study of Genetic and Environmental Contributions to Materialism." Personality and Individual Differences, 46, 428-431.

Gosling, S. D., P. J. Rentfrow, and W. B. Swann Jr. (2003). "A Very Brief Measure of the Big-Five Personality Domains." Journal of Research in Personality, 37, 504-528.

Grant, J. T., and T. J. Rudolph. (2003). "Value Conflict, Group Affect, and the Issue of Campaign Finance." American Journal of Political Science, 47, 453-69.

Green, D., B. Palmquist, and E. Shickler. (2002). Partisan Hearts and Minds. New Haven: Yale University Press.

Jacoby, W. G. (2000). "Issue Framing and Public Opinion on Government Spending." American Journal of Political Science, 44, 750-67.

Kiewiet, D. R. (1983). Macroeconomics and Micropolitics. Chicago: University of Chicago Press.

Kinder, D. R., and D. R. Kiewiet. (1979). "Economic Grievances and Political Behavior: The Role of Personal Discontents and Collective Judgments in Congressional Voting." American Journal of Political Science, 23, 495-527.

Lewis-Beck, M. S. (1985). "Pocketbook Voting in U.S. National Election Studies: Fact or Artifact?" American Journal of Political Science, 29, 348-57.

MacKuen, M. B., R. S. Erikson, and J. A. Stimson. (1989). "Macropartisanship." American Political Science Review, 83, 1125-42.

MacKuen, M. B., R. S. Erikson, and J. A. Stimson. (1992). "Peasants or Bankers? The American Electorate and the U.S. Economy." American Political Science Review, 86, 597-611.

Maio, G. R., and J. M. Olson. (1998). "Values as Truisms: Evidence and Implications." Journal of Personality and Social Psychology, 74, 294-311.

Marcus, G. E., J. L. Sullivan, E. Theiss-Morse, and S. L. Wood. (1995). With Malice Toward Some: How People Make Civil Liberties Judgments. New York: Cambridge University Press.

McClosky, H., and J. Zaller. (1984). The American Ethos: Public Attitudes toward Capitalism and Democracy. Cambridge: Cambridge University Press.

Miller, Gary, and Norman Schofield. (2003). "Activists and Partisan Realignment in the United States." The American Political Science Review, 97 (2), 245-260.

Miller, W. E., and J. M. Shanks. (1996). The New American Voter. Cambridge: Harvard University Press.

Mondak, J. J. (2010). Personality and the Foundations of Political Behavior. New York: Cambridge University Press

Oxley, D. R., K. B. Smith, J. R. Alford, M. V. Hibbing, J. L. Miller, M. Scalora, P. K. Hatemi, and J. R. Hibbing. (2008). "Political Attitudes Vary with Physiological Traits." Science, 321, 1167-70. 
Roberts, B. W., O. S. Chernyshenko, S. Stark, and L. R. Goldberg. (2005). "The Structure of Conscientiousness: An Empirical Investigation Based on Seven Major Personality Questionnaires.” Personnel Psychology, 58, 103-39.

Richins, M. L. (2004). "The Material Values Scale: Measurement Properties and Development of a Short Form." Journal of Consumer Research, 31, 209-219.

Richins, M. L., and S. Dawson. (1992). "A Consumer Values Orientation for Materialism and Its Measurement: Scale Development and Validation.” Journal of Consumer Research, 19, 303-316.

Rokeach, M. (1973). The Nature of Human V alues. New York: Free Press.

Schwartz, S. H. (1992). "Universals in the Content and Structure of Values: Theoretical Advances and Empirical Tests in 20 Countries.” In Advances in Experimental Social Psychology, ed. M. P. Zanna. Orlando: Academic Press, (pp. 1-65).

Sears, D. O. (1993). "Symbolic Politics: A Socio-Psychological Theory.” In S. Iyengar and M. J. McGuire (eds.) Explorations in Political Psychology, pp. 113-149. Durham, NC: Duke University Press.

Sears, D. O., and C. Funk. (1991). "The Role of Self-Interest in Social and Political Attitudes." Advances in Experimental Social Psychology, 24, 1-91.

Sears, D. O., R. R. Lau, T. R. Tyler, and H. M. Allen Jr. (1980). "Self-Interest vs. Symbolic Politics in Policy Attitudes and Presidential Voting." American Political Science Review, 74, 670-684.

Smith, K. B., D. Oxley, M. V. Hibbing, J. R. Alford, and J. R. Hibbing. (2011). "Disgust Sensitivity and the Neurophysiology of Left-Right Political Orientations.” PLoS ONE 6(10):e25552.doi:10.1371/journal.pone.0025552.

Tang, T. L. (1992). “The Meaning of Money Revisited.” Journal of Organizational Behavior, 13, 197-202.

Tatzel, M. (2002). “'Money Worlds' and Well-being: An Integration of Money Dispositions, Materialism and Price-related Behavior." Journal of Economic Psychology, 23, 103-126.

Troisi, J. D., A. N. Christopher, and P. Marek. (2006). "Materialism and Money Spending Disposition as Predictors of Economic and Personality Variables." North American Journal of Psychology, 8 (3), 421-436.

Wallendorf, M., and E. J. Arnould. (1988). "My Favorite Things: A Cross-Cultural Inquiry into Object Attachment, Possessiveness and Social Linkage." Journal of Consumer Research, 14, 531 47.

Weinschenk, Aaron C. 2012. "Partisan Pocketbooks: The Politics of Personal Financial Evaluations." Social Science Quarterly 93(4): 968-987.

Zaller, J. R. (1992). The Nature and Origins of Mass Opinion. New York: Cambridge University Press. 
Table 1: Economic values Regressed on Demographics and Big Five Personality Traits

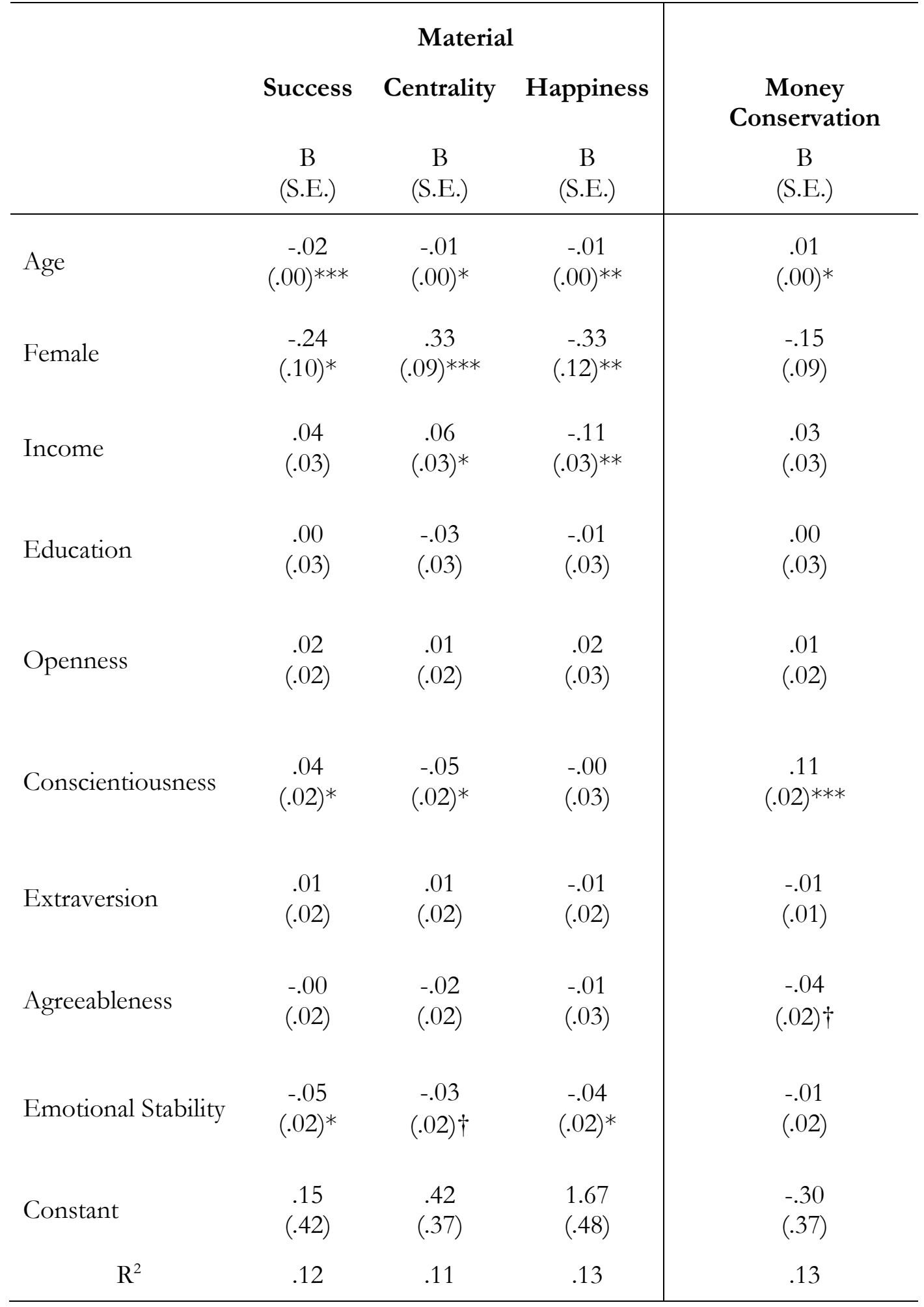

Notes: ${ }^{*} \mathrm{p}<.05,{ }^{*} \mathrm{p}<.01,{ }^{*} *{ }^{*} \mathrm{p}<.001, \dagger \mathrm{p}<.10$. 
Table 2: Bivariate Correlations Between Economic values, Ideology and Party Identification

\begin{tabular}{|c|c|c|c|c|c|c|}
\hline & Saving & Success & Centrality & Happiness & Ideology & Party ID \\
\hline \multicolumn{7}{|l|}{ Saving } \\
\hline Success & .03 & & & & & \\
\hline Centrality & $-.15^{* *}$ & $.29 * * *$ & & & & \\
\hline Happiness & -.04 & $.39 * * *$ & $.11 *$ & & & \\
\hline Ideology & $.12^{*}$ & .04 & $-.10 \dagger$ & .00 & & \\
\hline Party ID & .05 & -.01 & .01 & -.07 & $.68^{* * *}$ & \\
\hline
\end{tabular}


Table 3: Regression Results of Fiscal Policy Preferences on Economic values

\begin{tabular}{|c|c|c|c|c|}
\hline & $\begin{array}{c}\text { Wealth } \\
\text { Distribution }\end{array}$ & Lower Taxes & $\begin{array}{c}\text { Military } \\
\text { Spending }\end{array}$ & $\begin{array}{l}\text { Welfare } \\
\text { Spending }\end{array}$ \\
\hline Saving & $\begin{array}{c}.04 \\
(.07)\end{array}$ & $\begin{array}{c}.02 \\
(.06)\end{array}$ & $\begin{array}{l}-.05 \\
(.07)\end{array}$ & $\begin{array}{l}.03 \\
(.06)\end{array}$ \\
\hline Material Success & $\begin{array}{c}-.16 \\
(.08)^{*}\end{array}$ & $\begin{array}{l}-.08 \\
(.06)\end{array}$ & $\begin{array}{c}.03 \\
(.07)\end{array}$ & $\begin{array}{l}-.06 \\
(.06)\end{array}$ \\
\hline $\begin{array}{l}\text { Material } \\
\text { Centrality }\end{array}$ & $\begin{array}{c}.18 \\
(.08)^{*}\end{array}$ & $\begin{array}{c}.19 \\
(.05)^{* *}\end{array}$ & $\begin{array}{l}.09 \\
(.07)\end{array}$ & $\begin{array}{l}-.05 \\
(.07)\end{array}$ \\
\hline $\begin{array}{l}\text { Material } \\
\text { Happiness }\end{array}$ & $\begin{array}{c}-.25 \\
(.06)^{* * *}\end{array}$ & $\begin{array}{c}.10 \\
(.05) \dagger\end{array}$ & $\begin{array}{l}-.03 \\
(.06)\end{array}$ & $\begin{array}{l}.02 \\
(.06)\end{array}$ \\
\hline Ideology & $\begin{array}{c}.54 \\
(.05)^{* * *}\end{array}$ & $\begin{array}{c}.35 \\
(.04)^{* * *}\end{array}$ & $\begin{array}{c}.32 \\
(.05)^{* * *}\end{array}$ & $\begin{array}{c}.39 \\
(.04)^{* * *}\end{array}$ \\
\hline Age & $\begin{array}{l}.01 \\
(.01)\end{array}$ & $\begin{array}{l}-.00 \\
(.00)\end{array}$ & $\begin{array}{c}.02 \\
(.00) * * *\end{array}$ & $\begin{array}{l}.00 \\
(.00)\end{array}$ \\
\hline Female & $\begin{array}{c}-.41 \\
(.12)^{* *}\end{array}$ & $\begin{array}{c}.04 \\
(.10)\end{array}$ & $\begin{array}{l}-.03 \\
(.11)\end{array}$ & $\begin{array}{l}-.07 \\
(.10)\end{array}$ \\
\hline Income & $\begin{array}{c}.14 \\
(.04)^{* * *}\end{array}$ & $\begin{array}{l}-.06 \\
(.03)^{*}\end{array}$ & $\begin{array}{l}-.02 \\
(.03)\end{array}$ & $\begin{array}{c}.08 \\
(.03)^{*}\end{array}$ \\
\hline Education & $\begin{array}{l}.05 \\
(.03)\end{array}$ & $\begin{array}{c}-.11 \\
(.03)^{* * *}\end{array}$ & $\begin{array}{c}-.12 \\
(.03) * * *\end{array}$ & $\begin{array}{l}-.02 \\
(.03)\end{array}$ \\
\hline Constant & $\begin{array}{c}.62 \\
(.38)\end{array}$ & $\begin{array}{l}3.64 \\
(.31)\end{array}$ & $\begin{array}{l}2.14 \\
(.35)\end{array}$ & $\begin{array}{l}3.79 \\
(.33)\end{array}$ \\
\hline $\mathrm{R}^{2}$ & .39 & .29 & .20 & .25 \\
\hline
\end{tabular}

Notes: ${ }^{*} \mathrm{p}<.05,{ }^{*} \mathrm{p}<.01,{ }^{* * *} \mathrm{p}<.001, \dagger \mathrm{p}<.10 . \mathrm{n}=340 ;$ separate OLS regression used on each dependent variable. 